\section{Ivory in Kathmandu}

Elephant ivory is still on sale in Kathmandu, in Nepal, despite the fact that this transgresses the country's legislation. In a recent survey of 184 shops frequented by tourists 1454 ivory items were found for sale. Trade in ivory is at a vey low level, but dealers are still importing ivory. The Forest officers and police need to be motivated to confiscate the ivory and take the offenders to court. Without fully implementing Nepal's 25-year-old National Parks and Wildlife Conservation Act, the authorities are indirectly encouraging people to flout the restrictions.

\section{Introduction}

Nepal's geographical position and lax enforcement of its wildlife law have led the country to become a significant entrepôt for tiger bones, rhino horn, shahtoosh, musk, clouded leopard skins, bear bladder and ivory (Bauer, 1995; Wright and Kumar, 1997). There have been several surveys of the retail shops of the capital, Kathmandu, concentrating on rare cat skins and shahtoosh, the wool of the Tibetan antelope (Van Gruisen and Sinclair, 1992; Heinen and Leisure, 1993; Menon, 1994; Wright and Kumar, 1997). However, no study has been carried out on the display and sale of elephant ivory, which is totally banned by Nepalese law. In February 1998, I visited 184 souvenir and jewellery shops in Kathmandu's main tourist shopping areas and made an inventory of the ivory items: type of object, where it was produced and its retail price. I asked the shopkeepers about the nationalities of the buyers and about sales turnover. In addition, I interviewed the remaining carver in the most prominent Nepalese family of ivory craftsmen whom I had visited previously in 1982 and 1991.

\section{Recent history of the ivory-carving industry}

It is not known for how long ivory has been carved in Nepal, but in the Kathmandu Valley the main family making ivory items claims that its ancestors were carving ivory 300 years ago. Art historians believe that Nepal's ivory carving industry goes back at least to the 17th century, and some think it perhaps started as early as the eighth century (St Aubyn, 1987).

During the first part of the 20th century, craftsmen worked for members of the ruling Rana Dynasty (1846-1951), and for other wealthy Nepalese families. There were probably fewer than 30 ivory-carving families, and almost all worked in the town of Patan, just south of Kathmandu. Patan is the traditional home of Nepal's skilled craftsmen. In the middle of the century carved tusks were popular and items made from ivory included boxes, picture frames, Tibetan prayer wheels, necklaces, sculptures, combs, dice and handles for traditional knives (kukri). Few objects were exported, although occasionally sets of dice were sent to Tibet.

After the overthrow of the Ranas and subsequent political instability, demand for ivory dropped. It did not pick up again until the tourist boom in the 1970s. At that time the raw ivory came from a variety of sources. The Ranas, who had brought back large ivory tusks from hunting expeditions to Africa, sold them to craftsmen after they lost political and economic power. So did other formerly wealthy Nepalese who had acquired tusks as decoration for their houses. Merchants, who obtained raw ivory removed from working elephants in Nepal and through businessmen in India, also supplied the craftsmen. In 1982, carvers paid Rs500-600 (\$US38-46) per kg for broken and damaged ivory and Rs $1200-1500$ (\$US92-115) per $\mathrm{kg}$ for good quality tusks. The items made were generally ordered in advance by the shopkeepers and sometimes by private individuals. They wanted sculptures of gods, goddesses and animals. There was also a demand for small ivory window frames and ear picks. The maximum amount of money a skilled ivory craftsman could make, 
working full time in 1982, was \$US200 a month, considered to be a large sum at that time. There was strong competition from cheap ivory articles imported from Hong Kong, which caused some craftsmen to take up wood and yak-bone carving instead.

The ban on international commercial trade in ivory between Parties to the Convention on International Trade in Endangered Species (CITES), which came into effect in January 1990 as a result of the decision to list the African elephant on Appendix I of CITES, had an even greater impact on the Nepalese ivory craftsmen. The main ivory carving family in Patan purchased only $10 \mathrm{~kg}$ of ivory in 1990 and made about a dozen sculptures of gods and goddesses, and 15 prayer wheels. A year later, only a few people were still working full time in ivory. Sales of finished pieces had plummeted by over 70 per cent. On the other hand, the price for good-quality raw ivory rose to Rs8000 (\$US187) per $\mathrm{kg}$ because traders found it difficult to obtain. What supplies they could get came mostly from Royal Chitwan National Park and pieces collected in the southern town of Bharatpur.

\section{Ivory carving in Nepal today}

Although there had been eight members of the main ivory-carving family active in 1982, only one was still carving in 1998. He said that he believed he was the sole remaining ivory carver in the Kathmandu Valley. The small amount of raw ivory that he uses comes from. the trimmed tusks of domesticated elephants in Nepal. Shopkeepers usually bring the ivory to him to make statues of the Hindu god Ganesh and prayer wheels, for which he charges Rs200 (\$US3.25) a day for his labour, which is the same amount a skilled carpenter would earn. He told me that if he wanted to buy any raw ivory, he would have to pay Rs5000 (\$US81) per kg for poor quality parts of tusks and up to RS15,000 (\$US242) per kg for the best quality.

This ivory carver works at home, using at least 11 different metal tools that he has forged and an electric lathe that he purchased some time ago. He does not think there is any future for ivory carving in Nepal and consequently has not trained his son nor any other relative in his craft, breaking the family's centuries-old tradition.

\section{Survey of Kathmandu's souvenir and jewellery shops}

The 184 shops surveyed are in Lal Durbar, New Road, Thamel, Durbar Marg, Durbar Square and in the larger hotels, all places attracting tourists. Business was slow and the shopkeepers willingly gave their time to answer my questions and to tell me where their items were made. I examined objects for retail sale and found that 71 of the shops, or 39 per cent, had one or more items made out of elephant ivory. I saw a total of 1454 ivory articles for sale. When I asked if there were additional items, the shopkeepers told me that they had shown me almost all their pieces, because they wanted to display what they had in order to attract customers.

Just over half ( 53 per cent) of the ivory items were made in Nepal, 29 per cent came from China, 13 per cent from India, 4 per cent from Tibet and 1 per cent from Japan, according to the shopkeepers. Surprisingly, there was scarcely anything left from the Hong Kong imports. Not a single object had been made in Africa, and the only piece from Europe was an old brush that had been made in France. Of the 1454 items I saw, 40 per cent were sculptures, 13 per cent miniatures painted on ivory, 13 per cent netsukes (Japanese-style toggles), 12 per cent pendants, 10 per cent bangles, 2 per cent Chinese-style panels, 2 per cent necklaces, 1 per cent rings, 1 per cent boxes and 6 per cent miscellaneous pieces. There were some items made over 50 years ago in Nepal and Tibet, but most were less than 30 years old.

The ivory items for sale were the specialities of craftsmen of different nationalities. The Nepalese pieces were sculptures of Hindu gods and Asian animals, pendants, bangles, paintings and boxes. The Chinese pieces were sculptures, netsukes and painted panels. The 
Indian products were paintings, bangles, sculptures and necklaces while those from Tibet included hair ornaments, prayer beads, phurpas (for Buddhist rituals), sculptures and snuff boxes. Japanese articles were statues, seals and netsukes. The quality of the workmanship varied greatly, from carelessly carved animal figures and poorly executed paintings to superbly worked sculptures.

The retail value of the 1454 pieces was approximately Rs20,805,840 (\$US335,578). This figure is an estimate because sometimes the shopkeeper found it too tedious to state the price of every item, and instead gave a price range for similar objects. Undoubtedly also, a prospective customer could bargain and perhaps obtain as much as a 20 per cent discount.

None of the shops dealt in ivory exclusively, nor did ivory make up even half their items for sale. The most expensive ivory articles tended to be found in the jewellery shops. The highest priced item was a $30-\mathrm{cm}$-long chariot pulled by four horses; it had been carved in India and was offered for Rs260,000 (\$US4194). Of the Nepalese sculptures, a 20cm-high Garuda was the most expensive at Rs125,000 (\$US2016). The cheapest items were Nepalese rings for Rs50 (\$US0.80) each.

The shop owners had purchased Nepalesemade ivory articles from people walking in from the street, wanting cash; they had also commissioned pieces from craftsmen. Tibetan traders brought in ivory items from Tibet and China, along with religious scroll paintings, tea pots, snuff boxes, silver bowls and jewellery; sometimes these traders used the money they earned from selling their goods to the shops to pay for a journey to India to see the Dali Lama. Indian businessmen brought ivory sculptures, paintings and jewellery directly to the shops; and shop owners go occasionally to Rajasthan and Delhi to buy ivory products. The Japanese items belonged to a wealthy businessman running a souvenir shop in a hotel; he bought them in Japan in the early 1980 s to sell to Japanese tourists who visited Kathmandu, but more than 15 years later 21 of the items remained on his shelves.

The ivory retail trade in Kathmandu is now so slow that it is unprofitable. The value of

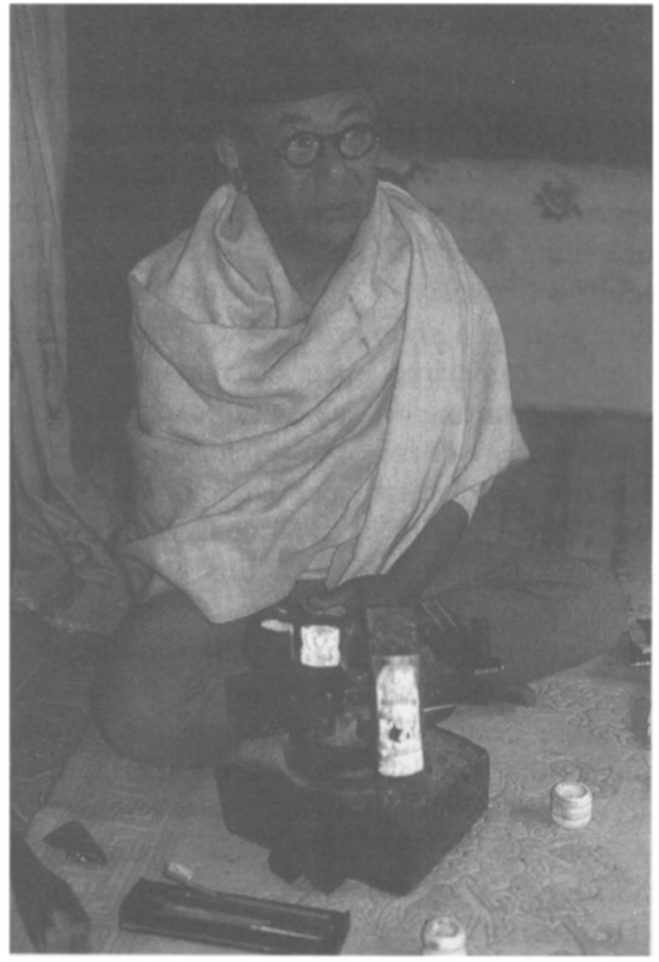

Although there is little demand for ivory carvings in Kathmandu, in early 1998 a curio shop commissioned this 65-year-old carver to make a Ganesh sculpture, which will take him 5 days to complete (Esmond Bradley Martin).

sales has fallen by more than 90 per cent since 1990. Citizens of Canada, the UK and the USA, who had been the main buyers, are no longer buying ivory in Nepal. Practically the only remaining customers are a few French, Germans, Italians, Japanese and Spanish. They prefer small items that can be concealed easily in their luggage. Nepalese used to buy religious statues but they seldom do so today because they cannot afford them. As a result of restrictions on the international commercial ivory trade, shop owners no longer try to export items wholesale. They claim that the ivory trade is dying and they attribute that almost entirely to the international ban. Nevertheless, sometimes a shop owner buys an article made in India, Nepal or Tibet because he thinks it will appeal to tourists. 


\section{Nepal's wildlife legislation}

The National Parks and Wildlife Conservation Act of 1973, which has been amended four times, is one of the strictest in the region, with severe penalties for killing protected animals or selling their products. The law even prohibits the display of such products, no matter how old, in a shop without a permit. When the law came into effect 25 years ago, shop owners wanting to sell wildlife products in stock were required to apply for a permit. No one ever applied for one, (Director General of the Department of National Parks and Wildlife Conservation, U. Sharma, and his predecessor, T. Maskey (pers. comms.). Thus all the ivory in Kathmandu's shops is illegal.

The Department of National Parks and Wildlife Conservation is responsible for implementing the law inside the parks and reserves. The Department of Forests is responsible for everywhere else, but it does not have a specific law enforcement unit (Heinen et al., 1995; Maskey, 1998). According to U. Sharma and T. Maskey (pers. comm.), Forest Department officials can search shops for endangered wildlife products, in co-operation with the police. The Customs Department has the authority to confiscate wildlife products going in and coming out of the country. However, the Management Authority for CITES in Nepal is the Department of National Parks and Wildlife Conservation, which, as noted above, has jurisdiction only inside protected areas.

In practice, no government authority monitors the sale of ivory in the souvenir and jewellery shops, which is why the shopkeepers continue to break the law. However, the Forest Department through the District Forest Office in Kathmandu does confiscate other wildlife products occasionally. In the last financial year and up to 12 February 1998, officers seized 7 leopard skins, 80 pieces of leopard bone, 1 leopard head, 1 bear bladder, 16 monkey heads, 57 tortoises, 1 musk deer pod, 1 python, $9.8 \mathrm{~kg}$ of tiger bones, 1 tiger skin and 2 rhino bones, according to S. Joshi, the Assistant Forest Officer in Kathmandu (pers. comm.).

\section{Conclusion}

Although the sale of ivory products is illegal and penalties for dealing in ivory are severe, it is carried on openly in Kathmandu's jewellery and souvenir shops. While at least two-thirds of the stocks pre-date 1990, shopkeepers continue to buy items recently imported from India and Tibet, and one Nepalese carver still supplies articles he makes. The fact that the market for ivory has declined sharply is not sufficient reason to ignore it. However, the authorities are doing just that: they are aware that the illicit trade in ivory exists but show no interest in stopping it. Forest Department officers and police need to be motivated to confiscate the ivory in the shops and prosecute the offenders. Without fully implementing Nepal's National Parks and Wildlife Conservation Act, the authorities are leaving the door open for infractions and are indirectly encouraging people to flout the restrictions.

\section{References}

Bauer, K. (ed). 1995. Illegal Trade of Wildlife Products in Nepal. WWF Program Report Series, No. 9. WWF, Kathmandu.

Heinen, J. and Leisure, B. 1993. A new look at the Himalayan fur trade. Oryx, 27 (4), 231-238.

Heinen, J., Yonzon, P. and Leisure, B. 1995. Fighting the illegal fur trade in Kathmandu. Conservation Biology, 9 (2), 246-248.

Maskey, T. 1998. The status of CITES implementation and trade of wild animals in Nepal. Ministry of Forests and Soil Conservation, Kathmandu (typewritten report).

Menon, V. 1994. Furs in Kathmandu, reprise. TRAFFIC Bulletin, 14 (3), 120.

St Aubyn, F. (ed). 1987. Ivory: an International History and Illustrated Survey. Harry Abrams, New York.

Van Gruisen, J. and Sinclair, T. 1992. Fur Trade in Kathmandu: Implications for India. TRAFFIC India, Delhi.

Wright, B. and Kumar, A. 1997. Fashioned for Extinction: an Exposé of the Shahtoosh Trade. Wildlife Protection Society of India, Delhi.

Esmond Bradley Martin PO Box 15510, Mbagathi Nairobi, Kenya

Received 8 May 1998

Accepted 18 June 1998

(C) $1998 \mathrm{FFI}$, Oryx $32(4), 317-320$ 